\title{
Protein NYNRIN
}

National Cancer Institute

\section{Source}

National Cancer Institute. Protein NYNRIN. NCI Thesaurus. Code C131769.

Protein NYNRIN (208 aa, $208 \mathrm{kDa}$ ) is encoded by the human NYNRIN gene. This protein may be involved in the mediation of DNA transposition. 